\title{
EFFECTS OF MANAGEMENT AND SUCCESSION PROCESS ON THE COMPOSITION OF VASCULAR HERBACEOUS PLANT SPECIES ALONG ROADSIDE AREAS IN POLAND
}

\author{
ŻOŁNIERCZUK, M. ${ }^{1}$ - FORNAL-PIENIAK, B. ${ }^{2 *}$ \\ ${ }^{1}$ Garden Department, Museum of King Jan III's Palace at Wilanów, Al. Rzeczypospolitej \\ 27A/48, 02-972 Warsaw, Poland \\ ORCID: 0000-0002-6267-0929 \\ ${ }^{2}$ Faculty of Horticulture and Biotechnology, Department of Environmental Protection and \\ Dendrology, Warsaw University of Life Sciences - SGGW, Nowoursynowska 166, 02-787 \\ Warszawa, Poland \\ ORCID: 0000-0002-3834-1105 \\ *Corresponding author \\ e-mail: beata_fornal_pieniak@sggw.edu.pl \\ (Received $21^{\text {st }}$ Feb 2020; accepted $7^{\text {th }}$ Jul 2020)
}

\begin{abstract}
Roadside areas are multifunctional elements of road surroundings (including their protective, socioaesthetic and biocenotic functions). The purpose of the article was to determine the impact of management and succession process on the herbaceous species composition of expressways roadsides in Poland. The research was conducted on the roadsides of expressways (S7, S8) in the Mazowieckie voivodship and the S17 express road in the Lubelskie voivodship in Poland. Three roadside zones were identified during this study. 29 transects were distinguished, in each of them 4 phytosociological records were taken. It was done analysis of plant species composition in projects, floral analysis and plant cover, phytosociological analysis, synoptic table and DCA, life forms, effects of the different factors as roads age, slope of the slope ${ }^{0}$, slope length on vegetation biodiversity. There were from four to five species of grass mixtures in roadside areas in the studied projects. Festuca rubra from $30 \%$ to $50 \%$ cover were dominating there. There were 116 species of vascular plants identified and they belong mostly to grasses communities such as Nardo-Callunetea (41\%) and MolinioArrhenatheretea $(31 \%)$. Mesohemerobes and perennial plants were dominating on roadside areas. Annual plants constitute $21 \%$ of the total while biennial plants as much as $5 \%$. The age of road has got impact on decrease number of plants form the Poaceae family and when the slope length increases, the level of biodiversity of vegetation increases, too. On the basis of the analyzed cases, the mixtures used for sowing roadside slopes have a poor composition. This is an unfavorable situation that does not guarantee species stability. In order to preserve the spread of species composition, additional financial outlays and actions implementing the principles of sustainable development are necessary.
\end{abstract}

Keywords: grasses, perennials, road surroundings, vegetation biodiversity

\section{Introduction}

Roadside areas are elements of road surroundings and carry important functions, i.e. safety, socio-aesthetic, biocenotic, air quality and service quality (Coffin, 2007; Tong et al., 2015; Chen et al., 2019). In recent years, the expressway network in Poland has been under development. Back in 2001, there was only $401.5 \mathrm{~km}$ of this class of roads, in 2016 there were already $1533.9 \mathrm{~km}$. By the beginning of $2018,30 \%$ of the planned expressways had been built, which is a clear disproportion between $85 \%$ of motorways completed. This simple data analysis shows how much new space will appear in Poland in the coming years, which well need to be developed using plants. Most publications about vegetation of roadsides elaborate on, trees and shrubs (Hasan et al., 2016; McGrath and Henry, 2016; Perea et al., 2019). This is probably due to the fact that trees 
and shrubs are most easily perceived and inventoried. Despite this, herbaceous vegetation is the largest contributor to roadside coverage. Its presence is appreciated by road users, who consider it proper to move trees and shrubs away from the edge of the road to create the so-called "belts forgiving drivers' mistakes" eng. forgiving roadside (Calvi, 2015). In Poland, even if trees often occur below them, only herbaceous vegetation is found. Thus, when analyzing the layout of the expressway, it should be stated that the herbaceous vegetation covers over $50 \%$ of the area of the road. Some authors, inter alia (Forman et al., 2003; Spooner and Smallbone, 2009; Kollarou and Kollaros, 2014) have observed that herbaceous roadside herbage is increasingly appreciated.

Currently, roadside slopes are mainly covered with grasses, which are one of the most resistant to road pollution plants (Koda et al., 2010). However, they do not always withstand other adverse habitat conditions (Niemandt and Greve, 2016). In Poland, this is related with, among others, the guidelines developed for establishing and maintaining roadside greenery for the needs of the General Directorate for National Roads and Motorways (GDDKiA) (Maranda et al., 2013) in which only two out the nine species listed are legumes that can be used to complete the mixture. It should be noted that there are studies indicating that the mixtures, e.g. Medicago lupulin, Lotus corniculatus (for various purposes) should be diversified (Koda et al., 2010). Unfortunately, this solution is rarely applied in Poland. The way of carrying out maintenance works on expressways in Poland has been presented, among others in the document "Guidelines for establishing and maintaining roadside greenery for the needs of the General Directorate for National Roads and Motorways" (Maranda et al., 2013). For safety reasons, 1-3 m wide strips closest to the road are cut more often (grass height should not exceed $10 \mathrm{~cm}$ ). For further areas, mowing 2-3 times a year is used. The grass is usually cut at a height of $5 \mathrm{~cm}$. Cut grass remains on the slopes. No other care treatments such as weeding or aeration are carried out. However, there are some problems related to the GDDKiA guidelines. System changes are currently being made to allow for less frequent mowing, which results, among others, from climate change - until now contractors have been obliged to carry out the number of mowing, as a result of which work was carried out even after snowfall or in hot weather, which resulted in drying out of low vegetation. Sowing is also being slowly implemented using seed mixtures for flower meadows. Polish producers have already developed a special blend composition that allows smog reduction (so-called "anti-smog seed mix"), appreciated at the international Smogathon competition.

Expressway roadsides were chosen for research because of the technical solutions and the volume of transport routes which affect the level of arduousness of road transport on the environment (Trombulak and Frissell, 2000; Pezeshki et al., 2018; AlTaani et al., 2019) and thus on the vegetation (Trombulak and Frissell, 2000; Truscott et al., 2005; Babcock and McLaughlin, 2011).

The purpose of the article was to determine the impact of management and succession process on the species composition of herbaceous on expressway roadsides.

Research hypothesis: The species composition of herbaceous vegetation depends on management and succession process on roadsides.

\section{Study area}

The research was conducted on the roadsides of expressways (S7, S8) in the Mazowieckie voivodship and the S17 express road in the Lubelskie voivodship in 
Poland (Figure 1). There are two-, five- and six-year-old expressways in this area. In order to determine the research areas, the following criteria were applied: location outside of a large city, area with potential deciduous forest habitat, neighboring agricultural area (an analysis carried out at a distance of $250 \mathrm{~m}$ from the road, with $50 \mathrm{~m}$ buffer off from buildings and noise barriers). All roadsides were sown artificially to the ground. Regardless of the location and exhibition of the escarpment, a sowing standard of $25 \mathrm{~g} / \mathrm{m}^{2}$ was used, which is in line with the rules set by most grass mix producers available in Poland. Sowing was carried out on a $10 \mathrm{~cm}$ thick layer of humus. The soil is sandy with thin leyer o humus along roadside.

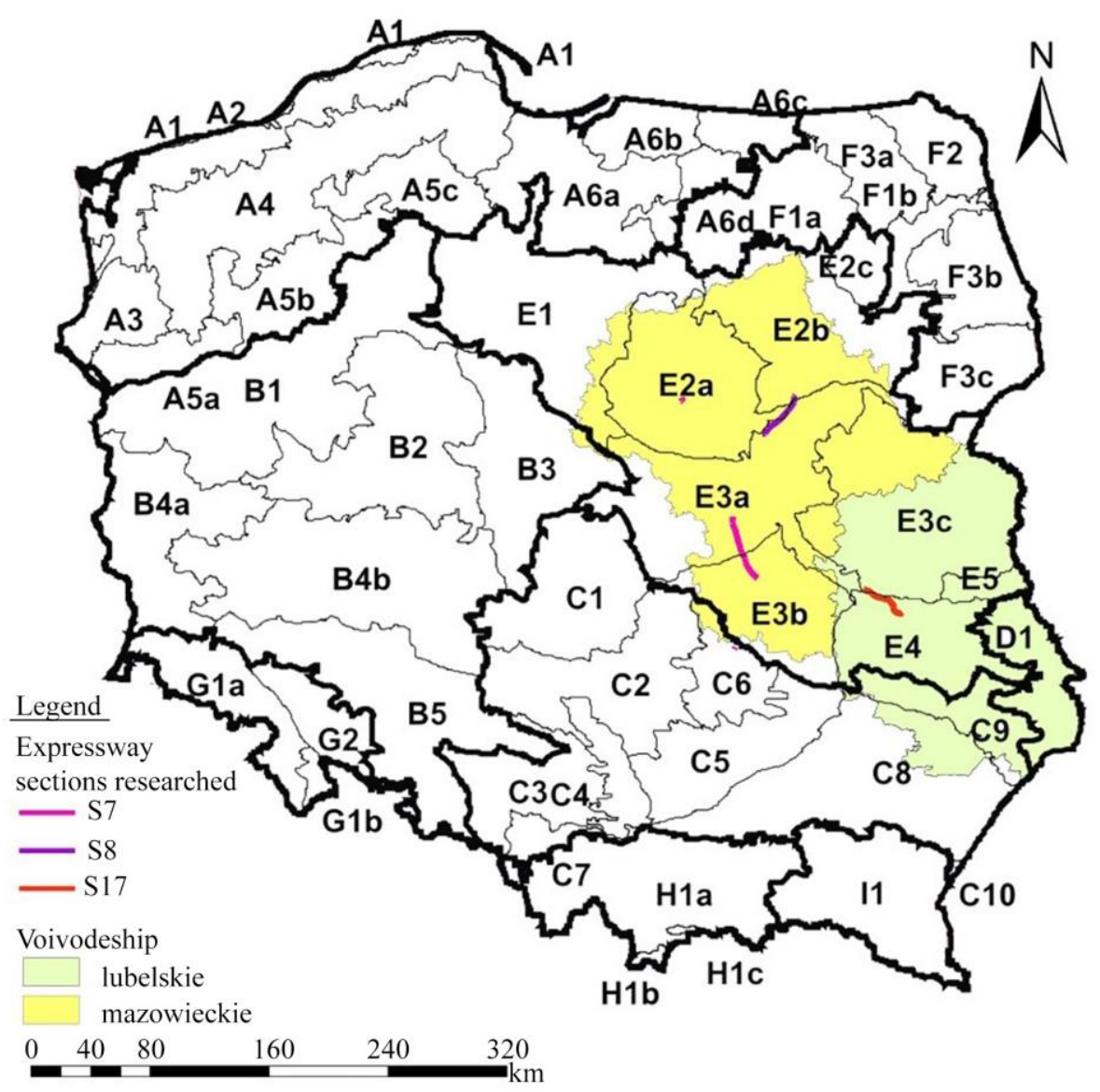

Figure 1. Research areas against the background of voivodships, as well as divisions, lands and sub-regions in the division of Poland's geobotanical regionalization (own study based on

Matuszkiewicz (1993)

The expressways have got the roadside areas, which do not include a gravel shoulder, which could no to be overgrown by vegetation. The rest areas were diversified by plants, some parts were intensively moved, the others less moved (Figure 2) The slope of the slopes is wide and ranges from $1^{\circ}$ to $50^{\circ}$. The lowest slope values are found on the flat surfaces behind the drainage ditch. High slope values (over $40^{\circ}$ ) occurred mainly on slopes located near road viaducts. The average slope inclination was about $32^{\circ}$. The greatest lengths are reached by the counter-slopes located behind the drainage ditch (length about $20 \mathrm{~m}$ ). The average length of the slopes is about $6 \mathrm{~m}$. 


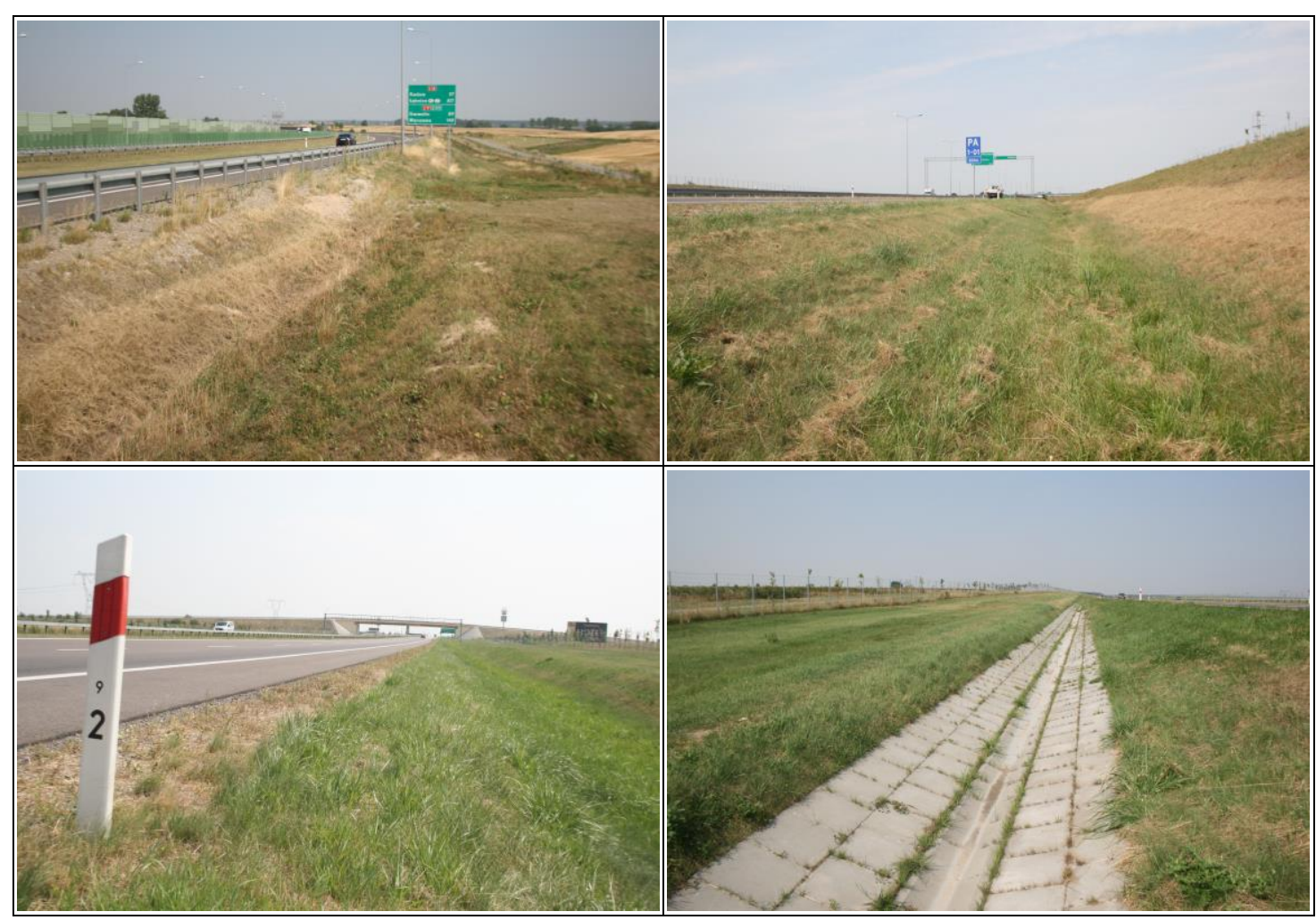

Figure 2. View on the roadside areas (photos: M. Żotnierczuk)

\section{Methods and statistical approach}

Research areas were designated using ArcGIS 10.5.1. At this stage, the design documentation of individual road sections was also analyzed. The composition of mixtures for sowing roadside areas available on the Polish market was carried out. Field studies were carried out and. the exact date of the survey was from 01.06. to 29.09 during the years 2016-2019.

Four roadside zones were identified during this study. 29 transects were distinguished, in each of them 4 phytosociological records were taken (one phytosociological record in each of the roadside zones). Coordnitates of research study plots (phytosociological records) were presented in Table 1. It was done 116 phytosociological records (one record was on $25 \mathrm{~m}^{2}$ were taken by Dzwonko (2007)). All plants were counted on studied plot (phytosociological records).

During the research, the focus was on the roadside area, which does not include a gravel shoulder (A), which could no to be overgrown by vegetation - that's why this area (zone) was not analyzed. The research area (one transect) was divided into 3 zones, the division of which resulted from observations during pilot studies:

Zone I - a belt about 1-3 m wide, intensively mowed, for safety reasons (the vegetation must not obstruct road markings, so-called "bollards").

Zone II - the width of the third lane varies greatly and depends on the total length of the slope. It is a belt less often mowed with a uniform plant cover. Because of wider this zone, two phytosociological records were taken in this zone: the middle of the escarpment and the bottom of the escarpment at the drainage ditch.

Zone III - is located next to the drainage ditch (Figure 3). 
Table 1. Coordnitates of research study plots (Geographic Coordinate System: GCS_ETRS_1989)

\begin{tabular}{|c|c|c|c|}
\hline $\begin{array}{c}\text { Number of } \\
\text { plots }\end{array}$ & Location & $\mathbf{X}^{*}$ & $\mathbf{Y}^{*}$ \\
\hline 1. & top of the escarpment & 21.130507 & 52.245953 \\
\hline 2. & middle of the escarpment & 21.130521 & 52.245942 \\
\hline 3. & down of the escarpment & 21.130536 & 52.245929 \\
\hline 4. & counterscarp & 21.130546 & 52.245921 \\
\hline 5. & top of the escarpment & 21.131884 & 52.251111 \\
\hline 6. & middle of the escarpment & 21.131930 & 52.251104 \\
\hline 7. & down of the escarpment & 21.131964 & 52.251099 \\
\hline 8. & counterscarp & 21.131998 & 52.251092 \\
\hline 9. & top of the escarpment & 21.133623 & 52.254509 \\
\hline 10. & middle of the escarpment & 21.133602 & 52.254512 \\
\hline 11. & down of the escarpment & 21.133577 & 52.254515 \\
\hline 12. & counterscarp & 21.133557 & 52.254517 \\
\hline 13. & top of the escarpment & 21.173512 & 52.273265 \\
\hline 14. & middle of the escarpment & 21.173508 & 52.273269 \\
\hline 15. & down of the escarpment & 21.173506 & 52.273271 \\
\hline 16. & counterscarp & 21.173501 & 52.273274 \\
\hline 17. & top of the escarpment & 21.135550 & 52.260838 \\
\hline 18. & middle of the escarpment & 21.135539 & 52.260847 \\
\hline 19. & down of the escarpment & 21.135523 & 52.260863 \\
\hline 20. & counterscarp & 21.135514 & 52.260879 \\
\hline 21. & top of the escarpment & 20.230601 & 52.374519 \\
\hline 22. & middle of the escarpment & 20.230581 & 52.374512 \\
\hline 23. & down of the escarpment & 20.230561 & 52.374503 \\
\hline 24. & counterscarp & 20.230515 & 52.374488 \\
\hline 25 . & top of the escarpment & 20.232107 & 52.364804 \\
\hline 26. & middle of the escarpment & 20.232122 & 52.364807 \\
\hline 27. & down of the escarpment & 20.232139 & 52.364809 \\
\hline 28. & counterscarp & 20.232154 & 52.364812 \\
\hline 29. & top of the escarpment & 21.194791 & 52.282403 \\
\hline 30. & middle of the escarpment & 21.194804 & 52.282385 \\
\hline 31. & down of the escarpment & 21.194814 & 52.282368 \\
\hline 32. & counterscarp & 21.194827 & 52.282355 \\
\hline 33. & top of the escarpment & 21.204706 & 52.285571 \\
\hline 34. & middle of the escarpment & 21.204734 & 52.285553 \\
\hline 35. & down of the escarpment & 21.204755 & 52.285543 \\
\hline 36. & counterscarp & 21.204777 & 52.285534 \\
\hline 37. & top of the escarpment & 21.243987 & 52.311755 \\
\hline 38. & middle of the escarpment & 21.244004 & 52.311746 \\
\hline 39. & down of the escarpment & 21.244020 & 52.311738 \\
\hline 40. & counterscarp & 21.244036 & 52.311731 \\
\hline 41. & top of the escarpment & 21.254634 & 52.320233 \\
\hline 42. & middle of the escarpment & 21.254646 & 52.320228 \\
\hline 43. & down of the escarpment & 21.254658 & 52.320221 \\
\hline 44. & counterscarp & 21.254672 & 52.320211 \\
\hline 45. & top of the escarpment & 21.274219 & 52.332497 \\
\hline 46. & middle of the escarpment & 21.274244 & 52.332466 \\
\hline 47. & down of the escarpment & 21.274270 & 52.332442 \\
\hline 48. & counterscarp & 21.274297 & 52.332405 \\
\hline
\end{tabular}




$$
-5826-
$$

\begin{tabular}{|c|c|c|c|}
\hline $\begin{array}{c}\text { Number of } \\
\text { plots }\end{array}$ & Location & $\mathbf{X}^{*}$ & $\mathbf{Y} *$ \\
\hline 49. & top of the escarpment & 21.274140 & 52.332554 \\
\hline 50. & middle of the escarpment & 21.274108 & 52.332573 \\
\hline 51. & down of the escarpment & 21.274063 & 52.332610 \\
\hline 52. & counterscarp & 21.274028 & 52.332647 \\
\hline 53 & top of the escarpment & 22.132280 & 51.234303 \\
\hline 54 & middle of the escarpment & 22.132280 & 51.234299 \\
\hline 55 & down of the escarpment & 22.132280 & 51.234274 \\
\hline 56 & counterscarp & 22.132281 & 51.234246 \\
\hline 57 & top of the escarpment & 22.140240 & 51.233195 \\
\hline 58 & middle of the escarpment & 22.140240 & 51.233181 \\
\hline 59 & down of the escarpment & 22.140240 & 51.233175 \\
\hline 60 & counterscarp & 22.140239 & 51.233167 \\
\hline 61 & top of the escarpment & 22.152160 & 51.231525 \\
\hline 62 & middle of the escarpment & 22.152160 & 51.231515 \\
\hline 63 & down of the escarpment & 22.152159 & 51.231503 \\
\hline 64 & counterscarp & 22.152160 & 51.231487 \\
\hline 65 & top of the escarpment & 22.161559 & 51.230380 \\
\hline 66 & middle of the escarpment & 22.161560 & 51.230374 \\
\hline 67 & down of the escarpment & 22.161560 & 51.230369 \\
\hline 68 & counterscarp & 22.161561 & 51.230360 \\
\hline 69 & top of the escarpment & 22.210000 & 51.220622 \\
\hline 70 & middle of the escarpment & 22.205997 & 51.220618 \\
\hline 71 & down of the escarpment & 22.205994 & 51.220614 \\
\hline 72 & counterscarp & 22.205991 & 51.220610 \\
\hline 73 & top of the escarpment & 22.231346 & 51.193209 \\
\hline 74 & middle of the escarpment & 22.231333 & 51.193210 \\
\hline 75 & down of the escarpment & 22.231322 & 51.193210 \\
\hline 76 & counterscarp & 22.231312 & 51.193211 \\
\hline 77 & top of the escarpment & 22.232060 & 51.200227 \\
\hline 78 & middle of the escarpment & 22.232051 & 51.200228 \\
\hline 79 & down of the escarpment & 22.232044 & 51.200228 \\
\hline 80 & counterscarp & 22.232038 & 51.200228 \\
\hline 81 & top of the escarpment & 22.232027 & 51.201148 \\
\hline 82 & middle of the escarpment & 22.232034 & 51.201150 \\
\hline 83 & down of the escarpment & 22.232044 & 51.201152 \\
\hline 84 & counterscarp & 22.232052 & 51.201154 \\
\hline 85 & top of the escarpment & 22.212506 & 51.215109 \\
\hline 86 & middle of the escarpment & 22.212520 & 51.215114 \\
\hline 87 & down of the escarpment & 22.212534 & 51.215118 \\
\hline 88 & counterscarp & 22.212550 & 51.215124 \\
\hline 89 & top of the escarpment & 22.193357 & 51.223460 \\
\hline 90 & middle of the escarpment & 22.193360 & 51.223482 \\
\hline 91 & down of the escarpment & 22.193360 & 51.223491 \\
\hline 92 & counterscarp & 22.193360 & 51.223501 \\
\hline 93 & top of the escarpment & 22.140960 & 51.233188 \\
\hline 94 & middle of the escarpment & 22.140968 & 51.233194 \\
\hline 95 & down of the escarpment & 22.140978 & 51.233200 \\
\hline 96 & counterscarp & 22.140986 & 51.233207 \\
\hline 97 & top of the escarpment & 22.100455 & 51.252644 \\
\hline 98 & middle of the escarpment & 22.100473 & 51.252652 \\
\hline
\end{tabular}




\begin{tabular}{c|c|c|c}
\hline $\begin{array}{c}\text { Number of } \\
\text { plots }\end{array}$ & Location & $\mathbf{X}^{*}$ & Y* \\
\hline 99 & down of the escarpment & 22.100487 & 51.252661 \\
100 & counterscarp & 22.100502 & 51.252666 \\
101 & top of the escarpment & 22.075522 & 51.260096 \\
102 & middle of the escarpment & 22.075523 & 51.260098 \\
103 & down of the escarpment & 22.075525 & 51.260101 \\
104 & counterscarp & 22.075526 & 51.260103 \\
105 & top of the escarpment & 22.085278 & 51.254959 \\
106 & middle of the escarpment & 22.085280 & 51.254961 \\
107 & down of the escarpment & 22.085283 & 51.254964 \\
108 & counterscarp & 22.085285 & 51.254966 \\
109 & top of the escarpment & 22.090353 & 51.254770 \\
110 & middle of the escarpment & 22.090360 & 51.254775 \\
111 & down of the escarpment & 22.090368 & 51.254783 \\
112 & counterscarp & 22.090374 & 51.254786 \\
113 & top of the escarpment & 22.084187 & 51.255277 \\
114 & middle of the escarpment & 22.084196 & 51.255284 \\
115 & down of the escarpment & 22.084205 & 51.255291 \\
116 & counterscarp & 22.084212 & 51.255295 \\
\hline
\end{tabular}

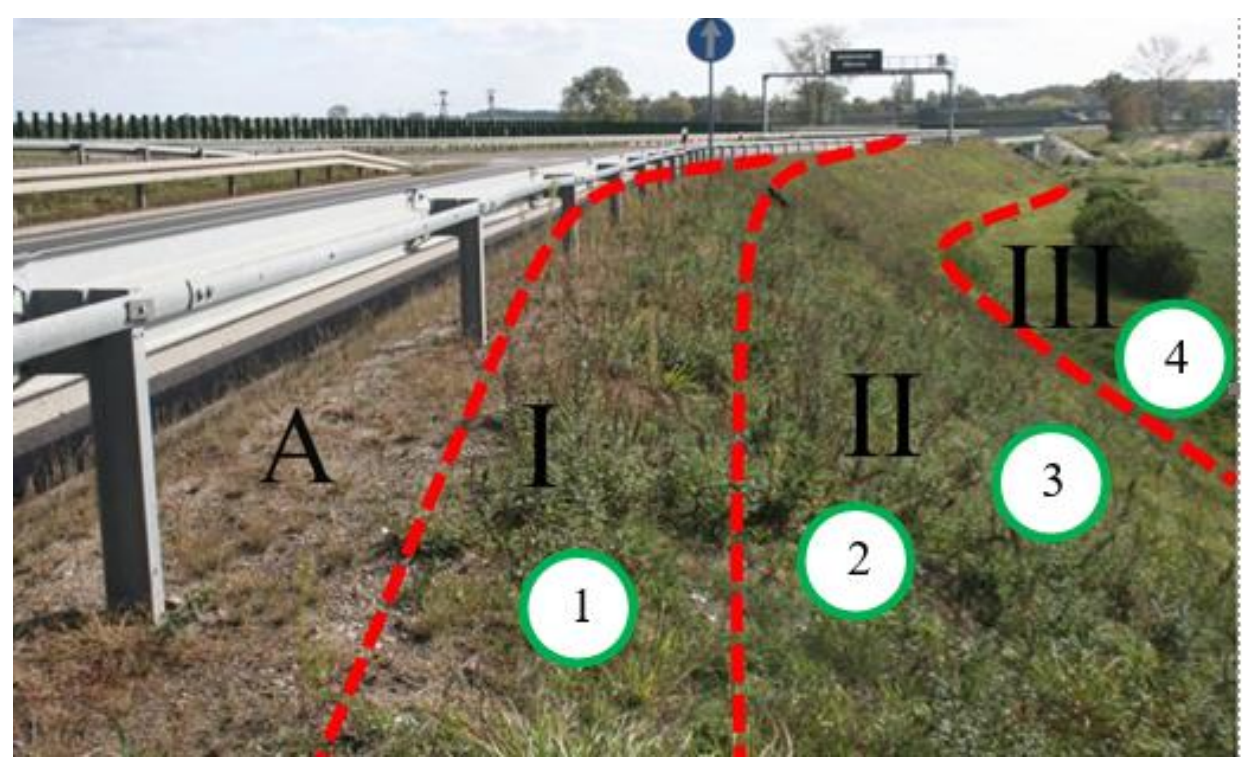

Figure 3. Schemate of study transect: A- area (zone) not analyzed I, II, III-zones, 1, 2, 3, 4 phytosociological records (own research)

For the determination of plants, the key was used to identify vascular plants of lowland Poland (Rutkowski, 2004), species names were adopted after Mirek et al. (2002) and plant communities were conducted according to Matuszkiewicz (2012).

By using the 10 degree hemeroby scale (from ahemerob (natural) to metahemerobic (community completely destroyed)) there were measure a departure from naturalness. For this purpose, data from the scientific database BiolFlor were used. The Juice 5.0 program was used to determine the Shannon index (Shannon and Weaver 1963). A synoptic table was created using the TWINSPAN method - in this way, types of 
communities have been specified, characterized by different species composition. Then DCA multifactorial analyzes were performed in the Canoco 5 program - it was used to illustrate the relationship between occurring species and the age of the road. The last stages of the study are the discussion and the conclusions.

\section{Results}

\section{Analysis of plant species composition in projects}

There were from four to five species of grass mixtures in roadside areas in the studied projects. Festuca rubra from $30 \%$ to $50 \%$ cover were dominating there. Roadside sections with a majority of Festuca ovina up to $50 \%$ and Lolium perenne up to $40 \%$ were also noticed. For sowing, it was recommended to use the species indicated by the General Directorate for National Roads and Motorways. None of the designed mixtures included an extra share of other plants, e.g. papilionaceous plants. The situation is an example illustrating the state of mixtures used for sowing roadsides in Poland. Based on the carried out analyzes, it was found that mixtures containing from 3 to 7 species are available on the Polish market, with $40 \%$ being mixtures containing 4 plant species. The key species in the mixtures are the above-mentioned Festuca rubra, Festuca ovina, Lolium perenne. The Shannon biodiversity index of the analyzed mixtures ranged from 0.64 to 1.75 . It should be noted that on the market there are also several mixtures of flower meadows intended for roadside areas, whose biodiversity index ranged from 2.40 to 3.8. These types of mixtures in roadside areas are applied only sporadically.

\section{Floral analysis and plant cover}

There were 116 species of vascular plants identified. The majority (91 species) were native species, whose share in the coverage of roadside slopes was $96.78 \%$ on average. The identified species belonged to 29 families, of which the Asteraceae ( 28 species) and the Poaceae (20 species) clearly stood out in terms of the number of species. Additionally, a relatively high share of the Fabaceae family (9 species) was recorded. The prevalence of the families mentioned above is also visible in the analysis of the degree of coverage but in this case the Poaceae family dominates $(81 \%)$, Asteraceae amounts only to approximately $7 \%$, and the Fabaceae share exceeds just over $1 \%$ (Table 2).

The share of other individual families was negligible and did not exceed $1 \%$ on average. Among the species from the Poaceae family, Agrostis gigantea and Agrostis capillaris clearly stood out with an average share of $26.69 \%$ and $26.32 \%$, respectively. A high average share was also noted in the case of Lolium perenne $-16.33 \%$, Festuca rubra $-8.23 \%$, and Elymus repens $-5.23 \%$. The individual share of other species from Poaceae did not exceed $4 \%$. The average share of individual species from Asteraceae did not exceed $1.5 \%$. The most numerous were Artemisia vulgaris $(1.41 \%)$ and Achillea millefolium (1.36\%). As many as 5 species are invasive species of Conyza canadensis, Erigeron annuus, Galinsoga parviflora, Solidago canadensis, Solidago gigantea, whose overall average share is $1.18 \%$. The plant cover was about $95 \%$ - this situation was similar in the case of all roadsides, with the lowest average value occurring on the fiveyear-old and six-year-old roadsides where it amounted to $92 \%$ (The whole recognized plant species in each phytosociological record are in Excel file). 
Table $2 \boldsymbol{a}, \boldsymbol{b}, \boldsymbol{c}$. The average share of plant species from dominated families as Poaceae, Asteraceae, Fabaceaa on roadsides

\begin{tabular}{|c|c|c|c|c|}
\hline \multicolumn{5}{|l|}{ a, } \\
\hline \multirow{2}{*}{$\begin{array}{c}\text { Poaceae } \\
\text { Specie names }\end{array}$} & \multicolumn{4}{|c|}{ Age of roadsides } \\
\hline & 2 & 5 & 6 & 16 \\
\hline Agrostis capillaris & $51.24 \%$ & $10.00 \%$ & $0.00 \%$ & $0.00 \%$ \\
\hline Agrostis gigantea & $37.84 \%$ & $27.45 \%$ & $19.00 \%$ & $42.14 \%$ \\
\hline Agrostis stolonifera & $49.00 \%$ & $0.00 \%$ & $0.00 \%$ & $55.00 \%$ \\
\hline Arrhenatherum elatius & $10.00 \%$ & $1.00 \%$ & $0.00 \%$ & $0.00 \%$ \\
\hline Calamagrostis epigejos & $0.00 \%$ & $6.00 \%$ & $0.00 \%$ & $0.00 \%$ \\
\hline Dactylis glomerata & $0.00 \%$ & $12.00 \%$ & $7.50 \%$ & $0.00 \%$ \\
\hline Deschampsia caespitosa & $0.00 \%$ & $12.50 \%$ & $0.00 \%$ & $0.00 \%$ \\
\hline Digitaria ischaemum & $0.00 \%$ & $0.00 \%$ & $0.00 \%$ & $2.00 \%$ \\
\hline Elymus repens & $15.80 \%$ & 0.088 & $19.45 \%$ & $19.00 \%$ \\
\hline Festuca arundinacea & $0.00 \%$ & $10.00 \%$ & $30.00 \%$ & $0.00 \%$ \\
\hline Festuca ovina & $0.00 \%$ & $5.00 \%$ & $0.00 \%$ & $0.00 \%$ \\
\hline Festuca pratensis & $0.00 \%$ & $20.00 \%$ & $0.00 \%$ & $0.00 \%$ \\
\hline Festuca rubra & $0.00 \%$ & $35.83 \%$ & $41.67 \%$ & $30.00 \%$ \\
\hline Holcus lanatus & $14.90 \%$ & $0.00 \%$ & $0.00 \%$ & $0.00 \%$ \\
\hline Lolium perenne & $16.33 \%$ & $11.88 \%$ & $18.00 \%$ & $5.00 \%$ \\
\hline Phalaris arundinacea & $0.00 \%$ & $30.00 \%$ & $15.00 \%$ & $0.00 \%$ \\
\hline Poa angustifolia & $75.00 \%$ & $22.79 \%$ & $0.00 \%$ & $15.00 \%$ \\
\hline Poa trivialis & $10.00 \%$ & $0.00 \%$ & $0.00 \%$ & $0.00 \%$ \\
\hline Setaria glauca & $5.00 \%$ & $2.40 \%$ & $0.00 \%$ & $0.00 \%$ \\
\hline Setaria viridis & $0.00 \%$ & $9.50 \%$ & $7.00 \%$ & $5.00 \%$ \\
\hline \multicolumn{5}{|l|}{ b, } \\
\hline \multirow{2}{*}{$\begin{array}{l}\text { Asteraceae } \\
\text { Specie name }\end{array}$} & \multicolumn{4}{|c|}{ Age of roadsides } \\
\hline & 2 & 5 & 6 & 16 \\
\hline Achillea millefolium & $1.46 \%$ & $3.59 \%$ & $3.33 \%$ & $8.29 \%$ \\
\hline Artemisia campestris & $1.00 \%$ & $2.71 \%$ & $0 \%$ & $0.00 \%$ \\
\hline Artemisia vulgaris & $1.42 \%$ & $5.63 \%$ & $3.33 \%$ & $5.00 \%$ \\
\hline Bellis perennis & $0.00 \%$ & $1.00 \%$ & $0.00 \%$ & $0.00 \%$ \\
\hline Carduus crispus & $0.00 \%$ & $1.00 \%$ & $3.00 \%$ & $0.00 \%$ \\
\hline Centaurea jacea & $0.00 \%$ & $1.00 \%$ & $0.00 \%$ & $0.00 \%$ \\
\hline Centaurea rhenana & $0.00 \%$ & $2.00 \%$ & $0.00 \%$ & $0.00 \%$ \\
\hline Cichorium intybus & $1.50 \%$ & $3.00 \%$ & $2.00 \%$ & $5.00 \%$ \\
\hline Cirsium arvense & $1.25 \%$ & $5.00 \%$ & $3.00 \%$ & $5.00 \%$ \\
\hline Cirsium vulgare & $0.00 \%$ & $1.20 \%$ & $0.00 \%$ & $0.00 \%$ \\
\hline Conyza canadensis & $1.00 \%$ & $2.00 \%$ & $11.00 \%$ & $5.00 \%$ \\
\hline Erigeron annuus & $1.00 \%$ & $0.00 \%$ & $0.00 \%$ & $0.00 \%$ \\
\hline Galinsoga parviflora & $0.00 \%$ & $4.00 \%$ & $0.00 \%$ & $0.00 \%$ \\
\hline Helichrysum arenarium & $0.00 \%$ & $1.00 \%$ & $0.00 \%$ & $0.00 \%$ \\
\hline Hieracium pilosella & $0.00 \%$ & $0.00 \%$ & $1.50 \%$ & $0.00 \%$ \\
\hline Hieracium spilophaeum & $0.00 \%$ & $0.00 \%$ & $0.00 \%$ & $0.00 \%$ \\
\hline Leontodon autumnalis & $1.00 \%$ & $0.00 \%$ & $0.00 \%$ & $0.00 \%$ \\
\hline Matricaria chamomilla & $0.00 \%$ & $1.40 \%$ & $2.00 \%$ & $0.00 \%$ \\
\hline Matriciara maritima & $1.50 \%$ & $1.50 \%$ & $0.00 \%$ & $3.00 \%$ \\
\hline Senecio viscosus & $0.00 \%$ & $2.00 \%$ & $5.00 \%$ & $0.00 \%$ \\
\hline Senecio vulgaris & $0.00 \%$ & $2.00 \%$ & $0.00 \%$ & $0.00 \%$ \\
\hline Solidago canadensis & $1.80 \%$ & $3.50 \%$ & $1.00 \%$ & $0.00 \%$ \\
\hline Solidago gigantea & $1.00 \%$ & $10.00 \%$ & $0.00 \%$ & $5.00 \%$ \\
\hline
\end{tabular}




$$
-5830-
$$

\begin{tabular}{c|cccc} 
Sonchus arvensis & $2.25 \%$ & $1.80 \%$ & $0.00 \%$ & $4.50 \%$ \\
Sonchus oleraceus & $1.00 \%$ & $1.00 \%$ & $0.00 \%$ & $4.00 \%$ \\
Tanacetum vulgare & $0.00 \%$ & $5.36 \%$ & $2.00 \%$ & $0.00 \%$ \\
Taraxacum officinale & $2.00 \%$ & $2.40 \%$ & $0.00 \%$ & $0.00 \%$ \\
Tussilago farfara & $0.00 \%$ & $0.00 \%$ & $0.00 \%$ & $10.00 \%$ \\
\hline c, & \multicolumn{4}{|c}{ Age of roadsides } \\
\hline Fabaceaa & \multicolumn{5}{|c}{$\mathbf{6}$} \\
Specie names & $\mathbf{2}$ & $\mathbf{5}$ & $1.00 \%$ & $0.00 \%$ \\
\hline Lathyrus pratensis & $0.00 \%$ & $0.00 \%$ & $0.00 \%$ & $0.00 \%$ \\
Lotus corniculatus & $0.00 \%$ & $1.50 \%$ & $2.00 \%$ & $0.00 \%$ \\
Medicago falcata & $0.00 \%$ & $2.25 \%$ & $0.00 \%$ & $0.00 \%$ \\
Medicago lupulina & $0.00 \%$ & $4.00 \%$ & $1.67 \%$ & $4.00 \%$ \\
Vicia cracca & $1.20 \%$ & $5.71 \%$ & $2.00 \%$ & $0.00 \%$ \\
Vicia hirsuta & $1.50 \%$ & $0.00 \%$ & $6.00 \%$ & $0.00 \%$ \\
Vicia sativa & $0.00 \%$ & $0.00 \%$ & $3.00 \%$ & $0.00 \%$ \\
Vicia sepium & $0.00 \%$ & $0.00 \%$ & $0.00 \%$ & $0.00 \%$ \\
Vicia villosa & $0.00 \%$ & $2.40 \%$ &
\end{tabular}

\section{Phytosociological analysis}

Plant species belong to grasses communities such as Nardo-Callunetea (41\%) and Molinio-Arrhenatheretea (31\%). It was determined that $9 \%$ are accompanying species, $8 \%$ belong to grasslands, $6 \%$ are forest species, $3 \%$ of species belong to lagg, and $2 \%$ are species belonging to rushes (Table 3). Their distribution in land cover, however, varies depending on individual years of use. On young roadside (2 years after putting the road into service) there is a dominance of species characteristic of grasslands $(47 \%$ of the area) and pastures (44\% of the area). It is directly related to the selection of species of seed mixtures for sowing. Five to six years after the start of use, the share of species characteristic of pastures increases significantly (from $60 \%$ to $74 \%$ ). The share of ruderal species reaching $25 \%$ and accompanying species $(16 \%)$ is on the increase as well. Along 16-year-old roads, the communities stabilize further - the share of species characteristic of pastures increases $(67 \%)$, the share of ruderal and associated species drops down to $18 \%$ and $14 \%$.

Table 3. Share of characteristic plant species (\%) in different vegetation types

\begin{tabular}{c|c}
\hline Vegetation types & Share of characteristic species in \% \\
\hline Ruderal & 41 \\
Pasture & 31 \\
Accompanying species & 9 \\
Grasslands & 8 \\
Plantings & 6 \\
Lagg & 3 \\
Rushes & 2 \\
\hline
\end{tabular}

\section{Synoptic table and DCA}

The changes taking place in the species composition are also noticeable in the synoptic table taking into account their fidelity and frequency. TWINSPAN method and 6 groups (from A to F) were distinguished. Group C (49 phytosociological records) and 


$$
-5831 \text { - }
$$

D (47 phytosociological records) clearly stand out. In the case of phytosociological records taken along the $\mathrm{S} 17$ express road in the Lubelskie voivodeship, a relatively high level of homogeneity of the groups can be seen (species from group C dominate). An exemplary arrangement of groups in transects is presented in Table 4. Some plant species with high fidelity and frequency in the groups $\mathrm{A}-\mathrm{F}$ were distinguished: group A: Artemisia campestris, Cirsium arvense, Deschampsia caespitosa, Elymus repens, Rumex thyrsiflorus, group B: Artemisia campestris, Equisetum arvense, Festuca arundinacea, Poa angustifolia, group C: Agrostis capillaris, Agrostis gigantea Achillea millefolium, Plantago lanceolata, group E: Agrostis gigantea, Daucus carota, group F: Cardamine pratensis, Carduus crispus, Festuca rubra, Hieracium pilosella, Vicia sativa (Figure 4).

Table 4. Exemplary arrangement of groups in transects (own study)

\begin{tabular}{|c|c|c|c|c|c|c|c|c|c|}
\hline & \multicolumn{8}{|c|}{ Voivodship } \\
\hline & & \multicolumn{2}{|c|}{$\begin{array}{c}\text { Lubelskie } \\
\text { Voivodeship }\end{array}$} & \multicolumn{6}{|c|}{ Masovian Voivodship } \\
\hline \multicolumn{2}{|c|}{ Age of roadsides } & & & & & & & & \\
\hline \multirow{4}{*}{$\begin{array}{l}\text { Location on } \\
\text { slope }\end{array}$} & Peak of slopes & $\mathrm{C}$ & $\mathrm{A}$ & $\mathrm{B}$ & $\mathrm{D}$ & $\mathrm{D}$ & $\mathrm{D}$ & $\bar{D}$ & $\bar{D}$ \\
\hline & $\begin{array}{l}\text { Middle of the } \\
\text { slopes }\end{array}$ & $\mathrm{C}$ & $\mathrm{C}$ & $\mathrm{D}$ & B & D & $\mathrm{F}$ & $\mathrm{D}$ & $\mathrm{D}$ \\
\hline & $\begin{array}{l}\text { Area near the } \\
\text { drainage dich }\end{array}$ & $\mathrm{C}$ & $\mathrm{C}$ & $\mathrm{D}$ & B & $\mathrm{F}$ & $\mathrm{D}$ & $\mathrm{D}$ & $\mathrm{D}$ \\
\hline & Counterslope & $\mathrm{C}$ & $\mathrm{C}$ & $\mathrm{E}$ & $E$ & $\mathrm{D}$ & $\mathrm{D}$ & $\mathrm{E}$ & $\bar{D}$ \\
\hline
\end{tabular}

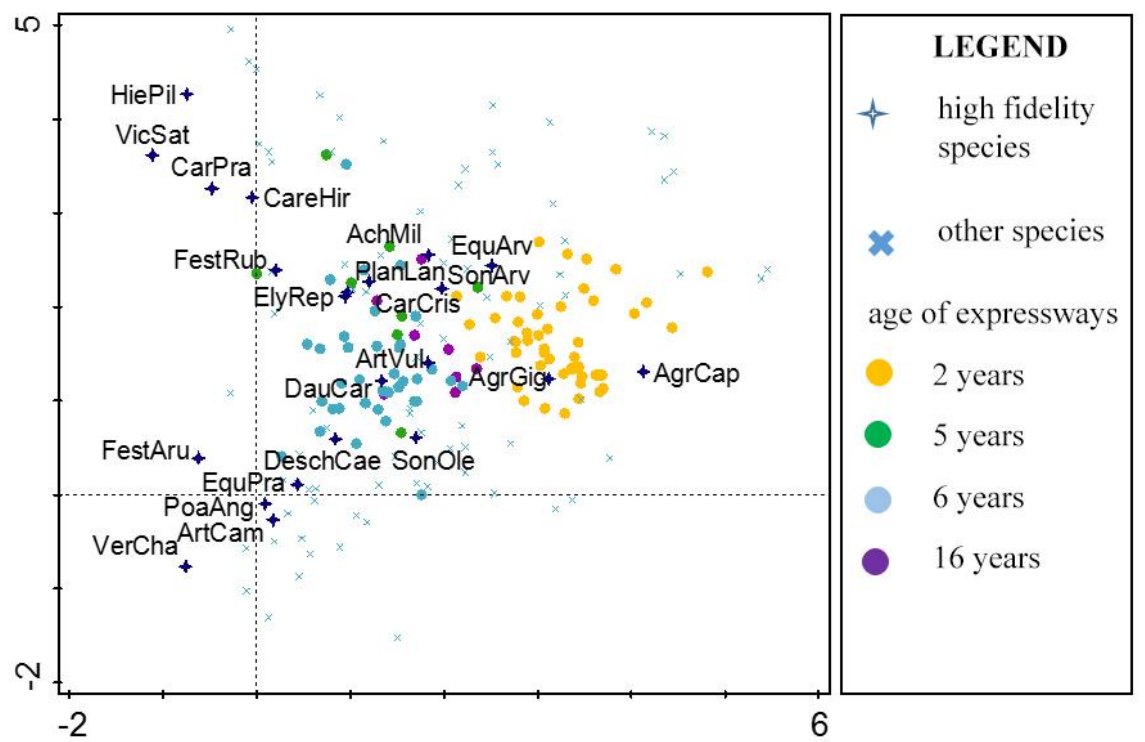

Figure 4. Multivariate DCA analysis - relationship between species composition and road age (own research)

Mesohemerobes plants were dominating, accounting for $25 \%$ of all plant species in general. Together with intermediate species between mesohemerobia and b-euhemerobia they constitute $47 \%$ of all species. The share of the remaining hemerobia groups was similar to each other ranging from $8 \%$ to $14 \%$. Considering the degree of 
coverage, grades 2 and $3(87 \%)$ dominate in the case of young roadside. On the roadsides aged 5-6 years, a-euhemerob (up to 35\%) dominates. After 16 years of use, stabilization and growth of grade 2 and 3 species of hemerobia occur (49\%) (Figure 5).

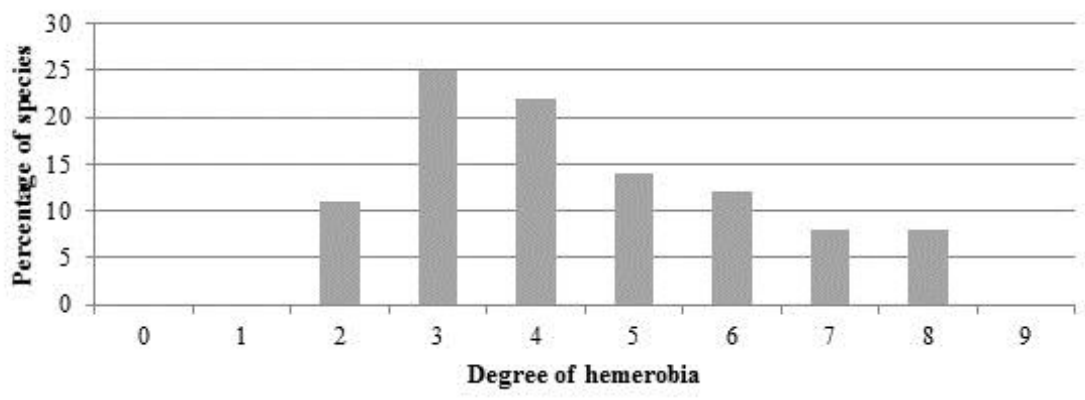

Figure 5. Distribution of species share relative to the degree of hemerobia: 0 - ahemerob, 1 oligohemerob (negligible human impact), 2 - intermediate form of $1 i$ 3, 3 - mezohemerob (moderate human impact), 4 - intermediate form of 3 i 5, 5-b-euhemerob (strong human influence), 6

\section{Life forms}

Perennial species are dominating (74\% of the total number of species) on the studied areas. Annual plants constitute $21 \%$ of the total while biennial plants as much as $5 \%$. When examining the degree of coverage by individual species, the dominance of perennial species is clearly visible, which on $93 \%$ of roadsides occupy $93 \%$, five-year-old about $75 \%$, and 16-year-old - $88 \%$. Areas with incomplete short-circuits obtain the highest biodiversity indicators - unoccupied spots are inhabited by annual species. In places where the short circuit is greater, the value of the Shannon index decreases $(\mathrm{r}=-0,46636)$ (Figure 6).

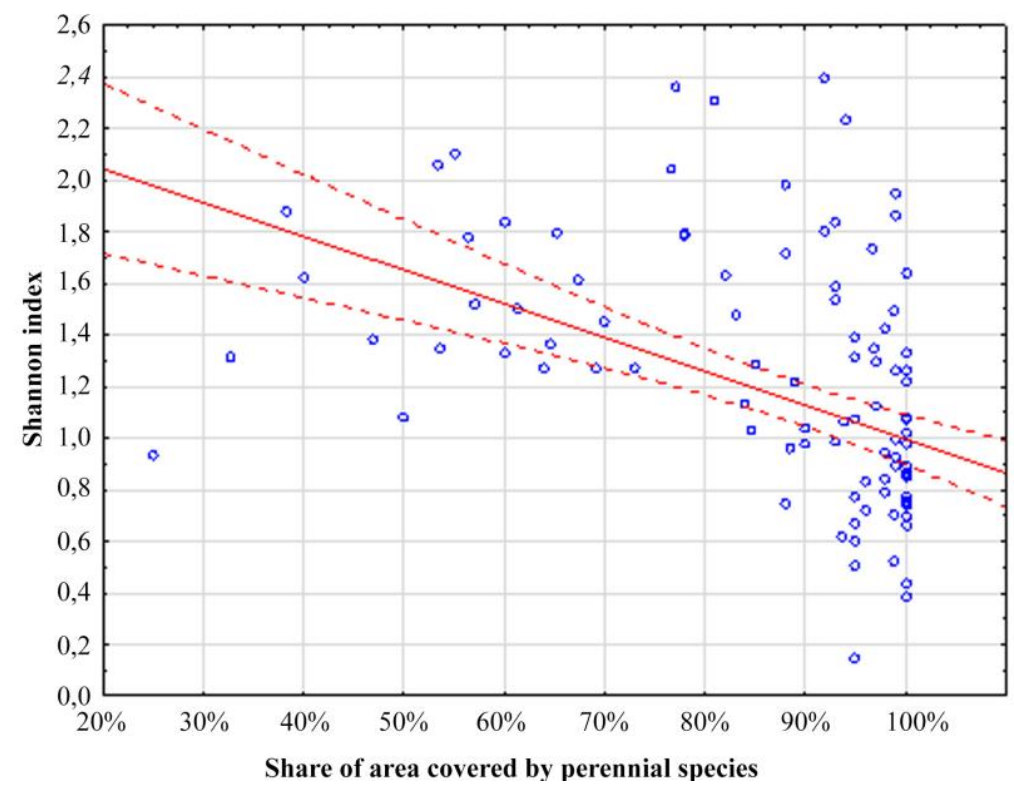

Figure 6. A scatter chart illustrating the impact of the share of perennial species in area covered on the level of the Shannon index, $r=-0,46636$ (own study) 


$$
-5833-
$$

\section{Effects of the different factors as roads age, slope of the slope ${ }^{0}$, slope lengt on vegetation biodiversity}

In the design documentation of the analyzed road sections it was assumed that the slopes would be sown with mixtures consisting only of grasses. During the phytosociological analysis, it was found that the share of species from the Poaceae family decreases with age of the roads (Figure 7). The resulting spaces are inhabited during succession mainly by species from the Asteraceae family (Figure 8).

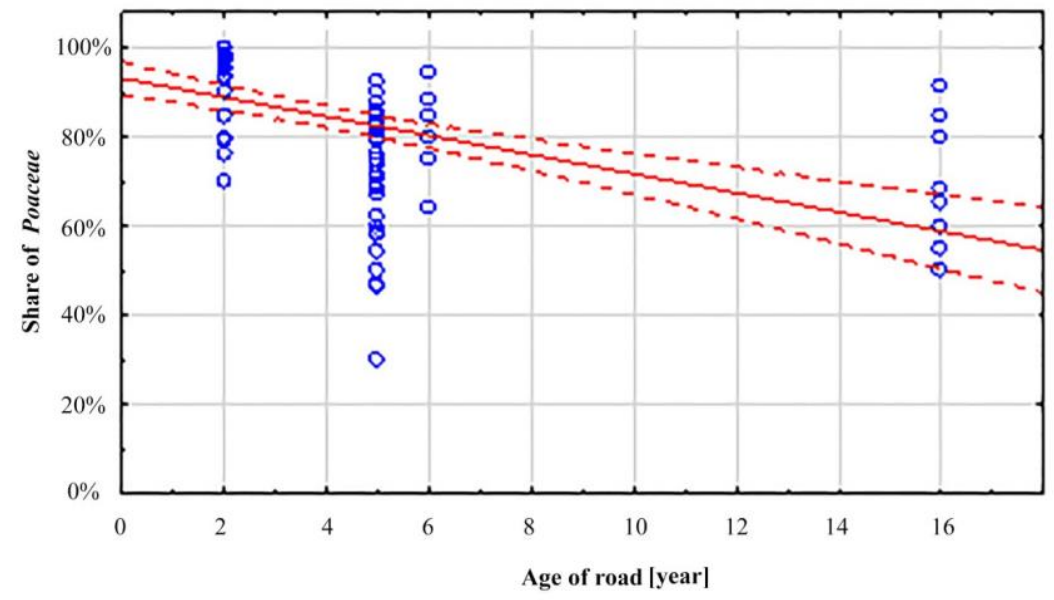

Figure 7. Share of plant species from Poaceae depending on the age of the road. $r=-, 5063$ (own study)

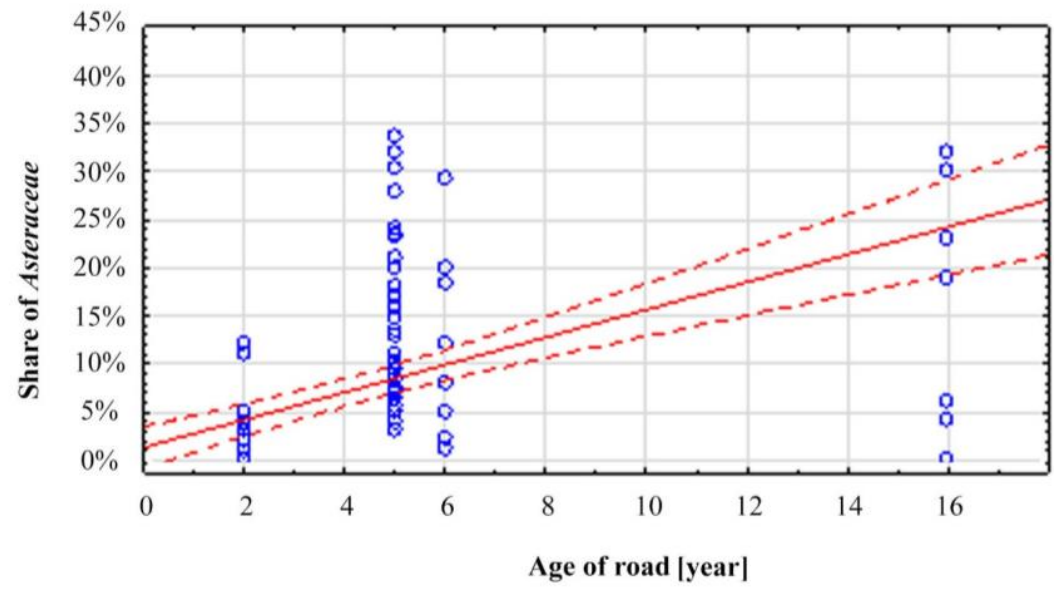

Figure 8. Share of plant species from Asteraceae depending on the age of the road. $r=-, 55091$ (own study)

The analyzes show that as the angle of inclination increases, the species diversity of the vegetation decreases (Figure 9). This is related to, among others with higher speed of water flowing along the slopes after precipitation - an increase in water speed causes easier detachment of seeds, which together with water move towards drainage ditches.

Based on the results obtained, it can be seen that as the slope length increases, the level of biodiversity increases (Figure 10). 


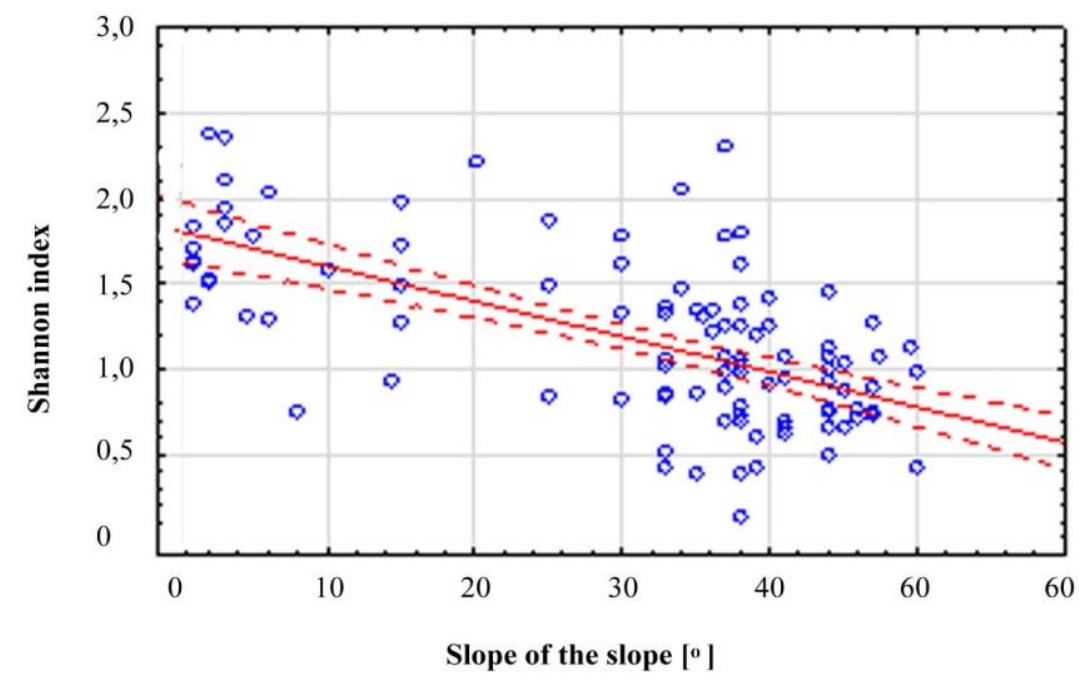

Figure 9. Shannon index depending on slope of the slope ${ }^{0}$ on the road in different ages. $r=-, 6085$ (own study)

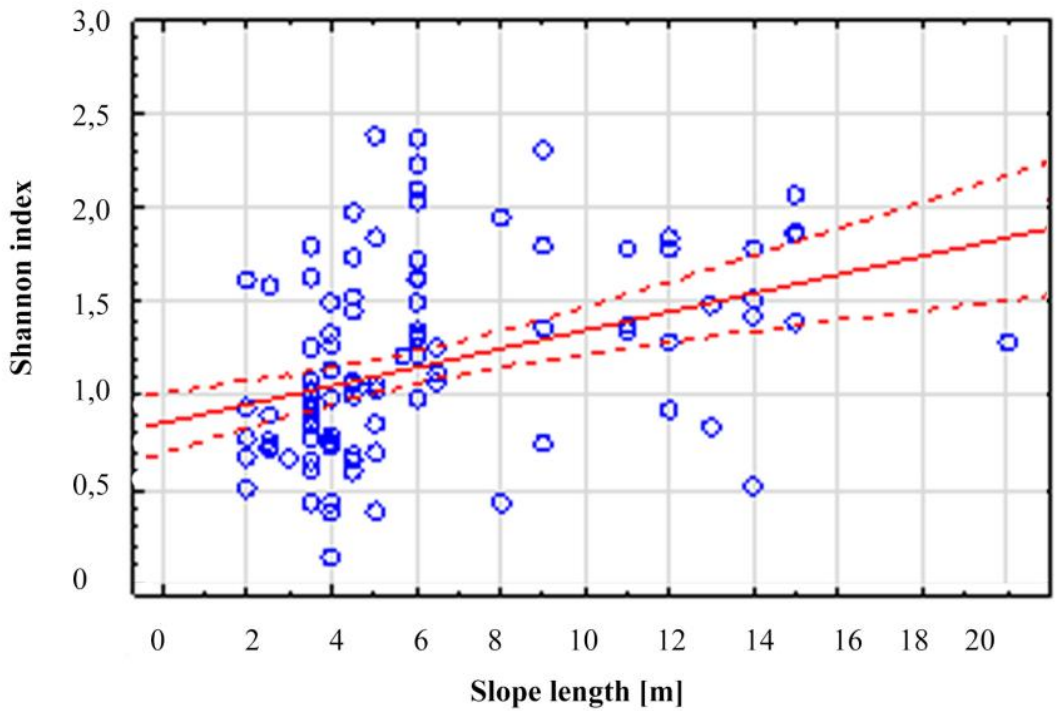

Figure 10. Shannon index depending on slope length on the road in different ages. $r=-, 36855$ (own study)

\section{Discussion}

Based on the conducted research, it was found that the formulated research hypothesis was true. In the course of the study, 116 plant species were identified. This result does not differ from the results of research by other authors conducted in the studied regions (for example, Trzaskowska and Adamiec (2012) were identified 110 plant species in Lublin) but also in other climatic regions: in the research of Hayasaka et al. (2012) in Japan was noted 122 species, Zeng et al. (2011) in the Yellow River delta recognized 100 plant species, and Arenas et al. (2017) along the highway near Madrid showed the presence of 130 plant species. Slight differences that appear may be due to 
the fact that some of the roadside areas studied by the authors were in the early stages of use. The smaller plant cover on some stands was mainly the result of technical conditions such as: lack of soil compaction, too small layer of fertile soil, large slope without additional reinforcements (geotextile, geotextile). These were the places where progressing erosion was visible (Xiao et al., 2017).

The roadside is dominated by native species (Forman et al., 2003; Szwed and Perkiewicz, 2010) which was confirmed in the research conducted by the authors where the share of alien and cultivated species slightly exceeded $3 \%$. Alien species are mainly ruderal species of commonly considered weeds. The adjacent roadsides can potentially promote the spread of these species, which raises farmers' concerns (Chaudron et al., 2016). Understanding the factors that shape roadside vegetation makes it possible to design programs that protect biodiversity, which limits the increase in weeds that can harm crops (Chaudron et al., 2018). The predominant share of native species is associated with the formation of corridors along the roads that allow native and alien species to move (Zeng et al., 2011; Arnadottir, 2012).

Perennial species were dominating, however, their share varies over time. Based on the conducted research, the authors concluded that the process of succession takes place over time, which is consistent with the situations described by (Wysocki, 1994). Over time, the species share may decrease by as much as $17 \%$ to $33 \%$ of land cover (Wysocki and Stawicka, 2000). A similar tendency was stated by Zeng et al. (2011). The author observed that after the initial low value of biodiversity of annual plant species, their diversity increases, which is in accordance with the view presented by Forman et al. (2003), and Pickett and McDonnell (1989). This demonstrates both the succession and competition between species. The proven dominance of perennial species confirms that they are more resistant to changes in the landscape than annual species (Linborg, 2007; Chaudron et al., 2018). The obtained test results prove the need to differentiate the species composition of roadside seeding mixtures in terms of life forms.

Mesohemerobic plants were dominating, which indicates a moderate anthropogenic impact. This proves, among other things, a small amount of care work, which is limited to extensive mowing 2-3 times a year. Minimization of outlays related to care positively effects the biodiversity of plant cover as it promotes changes in species composition and an increase in the number of species (Kull and Zobel, 1991; Bernhardt-Romermann et al., 2011).

The species composition of the roadside in the first years of use clearly differs from other years, as evidenced by the obtained test results. These results are evidence that the mixtures used and their composition require modification because the sown vegetation does not withstand difficult habitat conditions and the species composition changes.

The method of management impacts the dominance of species with a competition strategy. The method of mowing particularly influences the characteristics of plants associated with the strategy C (Klimesova et al., 2008; Chaudron et al., 2016; Fried et al., 2018). There is a high probability that a change in the composition of seed mixtures used for sowing slopes and a change in the way of vegetation care (e.g. by means of mowing) will contribute to creating a certain balance between competition, stress and disturbances enabling maintaining a high level of biodiversity (Bretzel et al., 2016). 


\section{Conclusions}

Herbaceous vegetation should be subject to rational and conscious design, constant control and care along the road lane for its proper quality and durability. These activities pose significant challenges for specialists within the realm of road problems. One of more important aspects is shaping the biodiversity of roadside spaces, which makes it possible to give them significance in the protection of native flora and fauna. Due to the direction of changes in the development of roadside space, the importance of biodiversity of herbaceous vegetation along roads will increase. One of the problems of poor vegetation associated with the appearance of areas without vegetation and progressive erosion on roadside is the manner of establishing herbaceous vegetation. As reported by Stabb et al. (2015) when selecting a seed mix, engineering constraints on roadside slopes, which are associated with specific conditions in a given area, should be taken into account as well as ensuring biodiversity. Thus, the right species selection of plants for roadside spaces makes it possible to give them importance in the protection of native flora as well as the fauna of agricultural landscapes (Spooner and Smallbone, 2009).

According to the European Landscape Convention it is necessary to take all measures to promote protection, management and landscape planning, including in roadside areas. Unfortunately, on the basis of the analyzed cases, it can be stated that the landscape's dissonance around expressways space is deepening. The mixtures used for sowing roadside slopes have a poor composition (up to 8 species). This is an unfavorable situation that does not guarantee species stability. In order to preserve the spread of species composition, additional financial outlays and actions implementing the principles of sustainable development are necessary. To promote the trend, it is advisable to diversify the composition of mixtures used in roadside areas with species from the Asteraceae and Fabaceae families. These are the species that after several years of use penetrate into empty roadside areas resulting from falling out plants that have not withstood harsh habitat conditions. In order to increase the level of biodiversity of roadside plant growing it is recommendable to apply annual and biennial species as well as ones with a high degree of hemerobia or species with a competition strategy $(\mathrm{C})$. The use of these species at the time of sowing will enable integration with the surrounding space, building biodiversity as well as strengthening security, including thanks to the varied space.

Acknowledgements. The authors are grateful to Professor Czesław Wysocki for his valuable methodical remarks.

\section{REFERENCES}

[1] Al-Taani, A. A, Nazzal, Y., Howari, F. M. (2019): Assessment of heavy metals in roadside dust along the Abu Dhabi-Al Ain National Highway, UAE. - Environmental Earth Sciences 78: 411. https://doi.org/10.1007/s12665-019-8406-X.

[2] Arenas, J. N., Escudero, A., Mola, I., Casado, M. A. (2017): Roadsides: an opportunity for biodiversity conservation. - Applied Vegetation Science 20: 527-537.

[3] Arnadottir, A. L. (2012): Turf transplants for restoration of alpine vegetation: does size matter? - Journal of Applied Ecology 49: 439-446. 


$$
-5837 \text { - }
$$

[4] Babcock, D. L., McLaughlin, R. A. (2011): Runoff water quality and vegetative establishment for groundcovers on steep slopes. - Journal of Soil and Water Conservation 66: 132-141.

[5] Bernhardt-Römermann, M., Römermann, C., Sperlich, S., Schmidt, W. (2011): Explaining grassland biomass - the contribution of climate, species andfunctional diversity depends on fertilization and mowing frequency. - Journal of Applied Ecology 48: 1088-1097.

[6] Bretzel, F., Vannucchi, F., Romano, D., Malorgio, F., Benvenut, S., Pezzarossa, B. (2016): Wildflowers: From conserving biodiversity to urban greening-A review. Urban Forestry and Urban Greening 20: 428-436.

[7] Calvi, A. (2015): Does roadside vegetation affect driving performance? Driving simulator study on the effects of trees on drivers' speed and lateral position. - Transportation Research Record: Journal of the Transportation Research Board 2518(1): 1-8.

[8] Chaudron, C., Chauvelb, B., Isselin-Nondedeu, F. (2016): Effects of late mowing on plant species richness and seed rain in road verges and adjacent arable fields. - Agriculture, Ecosystems and Environment 232: 218-226.

[9] Chaudron, C., Perronne, R., Bonthoux, S., Di Pietro, F. A. (2018): Stronger influence of past rather than present landscape structure on present plant species richness of road-field boundaries. - Acta Oecologica 92: 85-94.

[10] Chen, M. C., Hsu, C. L., Chen, M. M. (2019): How Transportation Service Quality Drives Public Attitude and Image of a Sustainable City: Satisfaction as A Mediator and Involvement as A Moderator. - Sustainability 11(23): 6813. https://doi.org/10.3390/su11236813.

[11] Coffin, A. W. (2007): From roadkill to road ecology: A review of the ecological effects of roads. - Journal of Transport Geography 15: 396-406.

[12] Database BiolFlor. - www.ufz.de.

[13] Dzwonko, Z. (2007): Guide book to phytosociological researches. - SORU 1-308.

[14] European Landscape Convencion, Florance, 20.10.2000. - www.coe.int.

[15] Forman, R. T. T., Sperling, D., Bissonette, J. A., Clevenger, A. P., Cutshall, C. D., Dale, V. H., Fahrig, L., France, R., Goldman, C. R., Heanue, K., Jones, J. A., Swanson, F. J., Turrentine, T., Winter, T. C. (2003): Road Ecology: Science and Solutions. - Island Press, Washington, D. C. 481 p.

[16] Fried, G., Villers, A., Porcher, E. (2018): Assessing non-intended effects of farming practices on field margin vegetation with a functional approach. - Agriculture, Ecosystems and Environment 261: 33-44.

[17] Hasan, R., Othman, N., Ismail, F. (2016): Roadside Tree Management in Selected Local Authorities for Public Safety. - Procedia - Social and Behavioral Sciences 234: 218-227.

[18] Hayasaka, D., Akasaka, M., Miyauchib, D., Box, E. O., Uchida, T (2012): Qualitative variation in roadside weed vegetation along an urban-rural road gradient. - Flora 207: 126-132.

[19] Klimesova, J., Latzel, V., de Bello, F., van Groenendael, J. M. (2008): Plant functional traits in studies of vegetation changes in response to grazing and mowing: towards a use of more specific traits. - Preslia 80: 245-253.

[20] Koda, E., Osiński, P., Głażewski, M. (2010): Agrotechnical strengthening of earthworks slopes. - Scientific Review - Engineering and Environmental Sciences 4: 36-47. (in Polish).

[21] Kollarou, V., Kollaros, G. (2014): Management of roadside vegetation, road-island planting and slope cover. - In: Liakopoulos, A., Kungolos, A., Christodoulatos, C., Koutsopsyros, A. (eds.) Proceedings of the 12th International Conference on Protection and Restoration of the Environment. ISBN 978-960-88490-6-8: 647-652.

[22] Kull, K., Zobel, M. (1991): High species richness in an Estonian wooded meadow. Journal of Vegetation Science 2: 715-718. 
[23] Maranda, K., Karpowicz, P., Kosek, M., Kucharska, M., Materek, T., Mleczko-Król, M., Musiel, M., Ochnio, P., Siedlecki, T., Stankiewicz, E., Wójcikowska, I. (2013): Guidelines for establishing and maintaining roadside greenery for the needs of the General Directorate for National Roads and Motorways. - GDDKiA, Warszawa, 72-73. (in Polish).

[24] Matuszkiewicz, J. M. (1993): Plant landscapes and geobotanical regions of Poland. PAN Wrocław, Warszawa, Kraków, pp. 66-83. (in Polish).

[25] Matuszkiewicz, W. (2012): Guide of plant communities in Poland. - PWN, Warszawa, 540 p. (in Polish).

[26] McGrath, D., Henry, J. (2016): Organic amendments decrease bulk density and improve tree establishment and growth in roadside plantings. - Urban Forestry and Urban Greening 20: 120-127.

[27] Mirek, Z., Piękoś-Mirkowa, H., Zając, A., Zając, M. (2002): Flowering plants and pteridophytes of Poland. A checklist. - W. Szafer Institute of Botany, Polish Academy of Sciences, Cracow.

[28] Niemandt, C., Greve, G. (2016): Fragmentation metric proxies provide insights into historical biodiversity loss in critically endangered grassland. - Agriculture, Ecosystems and Environment 235: 172-181.

[29] Pezeshki, Z., Soleimani, A., Darabi, A., Mazinani, S. M. (2018): Thermal transport in: Building materials. - Construction and Building Materials 181: 238-252.

[30] Pickett, S. T. A., McDonnell, M. J. (1989): Changing perspectives in community dynamics: A theory of successional forces. - Trends in Ecology and Evolution 4: 241-45.

[31] Piera, R., Cunha, J. S., Spadeto, C., Gomes, V. M., Moura, A. L., Rúbia, B., Fernandes, G. W. (2019): Nurse shrubs to mitigate plant invasion along roads of montane Neotropics. - Ecological Engineering 136: 193-196.

[32] Rutkowski, L. (2004): Key to determination of lowland Poland vascular plants. - PWN, Warszawa (in Polish).

[33] Shannon, C. E., Weaver, W. (1963): The mathematical theory of communication. Urbana, The Univ. of Illionois Press.

[34] Spooner, P. G., Smallbone, L. (2009): Effects of road age on the structure of roadside vegetation in south-eastern Australia. - Agriculture, Ecosystem Environment 129: 57-64.

[35] Staab, K., Yannelli, F. A., Lang, M., Kollmann, J. (2015): Bioengineering effectiveness of seed mixtures for road verges: Functional composition as a predictor of grassland diversity and invasion resistance. - Ecological Engineering 84: 104-112.

[36] Szwed, W., Perkiewicz, F. (2010): Floristic diversity of roadsides of selected communes of Greater Poland. - Bulletin of Wielkopolska Regional Parks 16: 68-89. (in Polish).

[37] Tong, Z., Whitlow, T. H., Macra, P. F., Landers, A. J., Harada, Y. (2015): Quantifying the effect of vegetation on near-road air quality using brief campaigns. - Environmental Pollution 201: 141-149.

[38] Trombulak, S. C., Frissell, C. A. (2000): Review of ecological effects of roads on terrestrial and aquatic communities. - Conservation Biology 14: 18-30.

[39] Truscott, A. M., Palmer, S. C. F., McGowan, G. M., Cape, J. N., Smart, S. (2005): Vegetation composition of roadside verges in Scotland: the effects of nitrogen deposition, disturbance and management. - Environmental Pollution 136: 109-118.

[40] Trzaskowska, E., Adamiec, P. (2012): Aesthetic value of extensive lawns on selected objects in Lublin. - Meadows in Poland 15: 193-203. (in Polish).

[41] Wysocki, C. (1994): Studies on the functioning of lawns in urban areas. - SGGW, Warszawa, 95 p. (in Polish).

[42] Wysocki, C., Stawicka, J. (2000): Assessment of floristic changes of urban lawn. Meadows in Poland 3: 169-176. (in Polish).

[43] Xiao, L. L., Yang, X. H., Cai, H. Y. (2017): The indirect roles of roads in soil erosion evaluation in Jiangxi Province, Chine: A large scale perspective. - Sustainbility 9: 129. doi: 10.3390/su9010129. 


$$
\text { - } 5839 \text { - }
$$

[44] Zeng, S. L., Zhang, T. T., Gao, Y., Ouyang, Z. T., Chen, J. K., Li, B., Zhao, B. (2011): Effects of road age and distance on plant biodiversity: a case study in the Yellow River Delta of China. - Plant Ecology 212: 1213-1229.

\section{ELECTRONIC APPENDIX}

This article has an electronic appendix with the basic field data. 